\title{
A Case Series of Ten Patients of Epidemic Dropsy June 2018 in a Tertiary Care Centre
}

\section{Satyendra Kumar Sonkar ${ }^{*},+, 1$, Satish Kumar ${ }^{2}$, Mahboob Alam $^{3}$, Virendra Atam ${ }^{4}$}

\author{
${ }^{1}$ Professor, Department of Medicine, King George's Medical University, Lucknow, India. \\ ${ }^{2}$ Senior Resident, Department Of Medicine King George's Medical University, Lucknow, India. \\ ${ }^{3}$ Junior resident Department of Medicine King George's Medical University, Lucknow, India. \\ ${ }^{4}$ Professor and Head, Department of Medicine King George's Medical University, Lucknow, India
}

ODOI: https://doi.org/10.15520/jcmro.v2i12.240

Accepted 15-12-2019; Received 12-11-2019; Publish Online 16-12-2019

Reviewed By:
Dr. K. Daniel
Department:
Reviewer/CMRO

\begin{abstract}
Epidemic dropsy (ED) occurs because of intoxication with alkaloid sanguinarine of Argemone Mexicana, the Prickly Poppy. Here we report a case series of ten patients, belonging to the same family, resident of a northern district in Uttar Pradesh, India. All of these admitted in June 2018 with pallor and erythematous bilateral pedal oedema. Our aim to report all these cases is to create awareness among people and to tell the importance of this malady, although it is illegal to sale mustard oil un-bottled in our country India.
\end{abstract}

Key words: Epidemic Dropsy-Argemone Mexicana-pancytopenia-cardiac failure

\section{INTRODUCTION:}

In India mustard oil is used as edible oil, as a result Epidemic dropsy (ED) generally occurs in these regions where this oil is regularly used[1].Oedema was formerly known as Dropsy, or hydropsy. Sanguinarine and dihydrosanguinarine are the quaternary ammonium salts found in alkaloid benzyl isoquinolone of Argemone (katkar) oil which is the main culprit of pathogenesis of epidemic dropsy. These two major alkaloids cause dilatation of blood vessels, proliferation and increased vascular wall permeability. These mechanisms are responsible for oedema as a result of leakage of protein-rich plasma from intravascular to the extracellular region. This oedema initially starts in bilateral lower limbs [1]. Mortality is due to cardiac failure leading to pulmonary oedema.

\section{CASE PRESENTATION:}

This case series of epidemic dropsy occurred in a northern district of Uttar Pradesh India, in a poor family with involvement of total ten family members. They were regularly consuming mustard oil, extracted from mustard seed purchased from nearby shop in their village. However on one

\footnotetext{
${ }^{\star}$ Corresponding author.

${ }^{\dagger}$ Email: satyendra.sonkar@gmail.com
}

night following consumption of heavy meal (non-vegetarian diet) at home, all family members developed breathlessness, pain abdomen, nausea, vomiting and diarrhoea. Head of the family, his wife, four sons, two daughter in laws and two grandsons were affected. One of the daughter in law who had haemoptysis and severe breathlessness expired at a local hospital. Family members got panicked and they presented at our hospital with fever, breathlessness, pain abdomen and erythematous bilateral pitting pedal oedema while one had haemoptysis. Eight (6 adults and 2 children) got admitted due to their severity of disease. All were conscious, oriented but anaemic and had tachycardia and were hypotensive.

Case 1 -A 55-year-old man, head of the family had GCSE4V5M6, pulse rate (PR) 110/minute (tachycardia), blood pressure (BP) 90/50 $\mathrm{mmHg}$ (hypotensive) and severely anaemic.Case 2 was 42 -year-old wife of case 1, had tachycardia (PR 112/min) and normotensive (blood pressure $130 / 70 \mathrm{mmHg}$ ) with raised jugular venous pressure.Case 3 was son of case $1 \& 2$, 30 years of age, had haemoptysis also. He was severely anaemic, had tachycardia and hypotensive (blood pressure 90/60 $\mathrm{mmHg}$ ) with raised jugular venous pressure. Case 4 was wife of above case 3, 22-yearold was hypotensive and severely anaemic. Case 5 was a baby of 4 years, son of case $3 \& 4$, admitted in Paediatric department and was severely anaemic. Case 6was 26 year old man son of case $1 \& 2$, had tachycardia ( $P R=112)$, hypotension (blood pressure $88 / 60 \mathrm{mmHg}$ ) and raised jugular 
venous pressure with severe anemia.Case 7 was 22 year old female wife of above case 6 , who had expired at local hospital due to cardiac failure.Case 8 was 18 year old male, son of case $1 \& 2$, was also severely anaemic and had tachycardia $(\mathrm{PR}=104 /$ minute $)$ and hypotension $(\mathrm{BP}=80 / 56$ $\mathrm{mmHg}$ ).Case 9 was 12 year old boy, maternal grandson of case 1 admitted in Paediatrics department was also severely anaemic.Case 10 ,son of case $1 \& 2$, age 20 was clinically stable and was managed on outpatient department basis.During their hospital stay following were the laboratory investigations of above admitted patients. Table 1 All the admitted patient had pancytopenia. Intraocular pressure was normal. Case 3 and 8 had retinal haemorrhage. Case 3 developed flexion deformity in bilateral knee joint and it gradually improved after physiotherapy. Case 6 deteriorated during hospital stay and required vasopressor with non-invasive ventilator support as he developed frank pulmonary oedema. Bone marrow aspiration of case 8 showed hypo cellularity. All were discharged after they symptomatically improved and were asked for regular follow up. The two children also were discharged from paediatric ward after they were clinically stable. Patients' haematological parameters improved after five months of admission and there was no pedal oedema.

\section{TREATMENT:}

There is no antidote/specific treatment for Argemone oil poisoning and its treatment is basically symptomatic along with removal of adulterated oil/offending agent from being used. Other supportive treatment that should be given are, bed rest, elevation of leg, supplementation of calcium, vitamins $\mathrm{C}$ and $\mathrm{E}$, protein rich diet, and thiamine. Diuretics are used to reduce oedema. Medical management or operative intervention may be needed in case of Glaucoma. Public education, mandatory quality inspections, and detection of possible contaminations may be the valuable measures to eradicate the ED.

Table 1

\section{DISCUSSION:}

Argemonemexicana (family: Papaveraceae) plant, the Mexican Prickly Poppy is extensively found in Mexico and North America. It has been shifted and naturalized to India because of trade practices [2] . ED is also known as 'Bharbhanda, 'Shailkanta', 'Satyanashi', and 'Pivladhatura' in different regions of India. The first case was seen in 1877 in Calcutta.Next was epidemic dropsy in New Delhi in the year 1998 [1]. After that small epidemics came in succession invarious cities of India like Lucknow, Kannauj, Gwalior, and the western Rajasthan [3]. ED is caused due to ingestion of adulteratedmustard oil, as well as ghee and wheat flour by oil from Argemone Mexicana [4] .Consumption and body massage with adulterated oil, both can lead to ED [5].Only the laboratory investigations can distinguish mustard oil from Argemone oil (nitric acid test). It is found that a minimum of $1 \%$ concentration of Argemone oil may be cause of ED [6]. Ramasastri and Babu have proposed a maximum permissible upper limit of $0.01 \%$ in edible oils [7]. Heart, liver, kidney, gastrointestinal tractand lungs are commonly affected in Argemone oil poisoning because sanguinarine get concentrated in these organs for a long period of about 96 hour [1]. Formation of reactive oxygen species (ROS) and lower levels of antioxidants decreases overall antioxidant levels in body (mainly vitamins $\mathrm{E}$ and $\mathrm{A}$ ) and damages liver enzymes [8]. As all our patients had tender, bilateral lower limb swelling with erythema which is the typical clinical feature of Argemone oil poisoning. Anemia could be attributed to toxic myelosuppression, shortened red cell life and gastrointestinal bleed. Our patients had high level of ferritin suggestive of chronic inflammation with deficient vitamin B12 and folic acid. Altered liver enzymes and hepatomegaly are other features though our patients did not had deranged liver function. Acute blindness because of raised intraocular pressure and retinal haemorrhage may also be found and it needs urgent surgical intervention. None of our patient had raised intra ocular pressure.Complete improvement takes about 3- 5 months after discontinuation of adulterated mustard oil [9].

Congestive cardiac failure, nephritic syndrome, myxoedema, beriberi and anaemia are the differentials of ED.

Acknowledgement: None

\section{REFERENCES}

[1] Das M, Khanna SK. Clinicoepidemiological, toxicological, and safety evaluation studies on argemone oil. Crit Rev Toxicol. 1997;27:273-297.

[2] Rangan C, Barceloux DG. Food Contamination. Disease-aMonth. 2009;55:263-91.

[3] Dhayal GL, Agarwal H, Mathur A, Mathur S, Kishoria N, Jain S. Case report of a small outbreak of epidemic dropsy. J Indi Med Assoc. 2013;111:200-201.

[4] Narasimhan C, Jg T, Thomas G, Israel J, Rao PS, Pulimood BM. Epidemic dropsy in Andhra Pradesh due to contaminated ghee. J Assoc Physicians India. 1991;39:749-750.

[5] Sood NN, Sachdev MS, Mohan M, Gupta SK, Sachdev HP Lal RB and Dasgupta AC. Investigations into the epidemiology of epidemic dropsy. Incidence by season. Trans R Soc Trop Med Hyg. 1942;79:145-145. Ind J Med Res.

[6] Lal RB and Dasgupta AC. Investigations into the epi- demiology of epidemic dropsy. Incidence by season. Ind J Med Res. 1942;30:145-145.

[7] Ramasastri BV, Babu S. A study on the toxicity of Argemone oil in experimental animals. Indian J Med Res. 1975;63:13531357.

[8] Eruvaram NR, Das M. Phenotype of hepatic xenobiotic metabolizing enzymes and CYP450 isoforms of sanguinarine treated rats: effect of $\mathrm{P} 450$ inducers on its toxicity. ToxicolMech Methods. 2009;19:510-517.

[9] Sharma BD, Malhotra S, Bhatia V, Rathee M. Epidemic dropsy in India. Postgrad Med J. 1999;75:657-661. 
Table 1. Results of laboratory and radiographic investigations of all the cases

\begin{tabular}{|c|c|c|c|c|c|c|}
\hline & Case 1 & Case 2 & Case 3 & Case 4 & Case 6 & Case 8 \\
\hline Age (years) & 55 & 42 & 30 & 22 & 26 & 18 \\
\hline Sex & Male & Female & Male & Female & Male & Male \\
\hline $\begin{array}{l}\mathrm{Hb}(15-17 \\
\mathrm{g} / \mathrm{dL})\end{array}$ & 5.8 & 9.1 & 5.8 & 6.5 & 5.8 & 5.8 \\
\hline $\begin{array}{l}\mathrm{TLC}(4- \\
11 \times 103 / \mu \mathrm{L})\end{array}$ & 4200 & 4700 & 2900 & 3600 & 2800 & 1800 \\
\hline $\begin{array}{l}\text { PLT }(150- \\
450 \times 103 / \mu \mathrm{L})\end{array}$ & 89000 & 1.17 & 90000 & 58000 & 55000 & 49000 \\
\hline $\begin{array}{l}\text { Reticulocyte- } \\
\text { count }(< \\
2 \%)\end{array}$ & $0.5 \%$ & $1 \%$ & $0.5 \%$ & $0.6 \%$ & $0.5 \%$ & $0.5 \%$ \\
\hline $\begin{array}{l}\mathrm{Na}(135-145 \\
\mathrm{mEq} / \mathrm{L})\end{array}$ & 139.6 & 141.7 & 139 & 135.6 & 138.2 & 143.6 \\
\hline $\begin{array}{l}\text { Urea(20-40 } \\
\mathrm{mg} / \mathrm{dL})\end{array}$ & 48.6 & 74.1 & 43 & 77 & 52.1 & 31.1 \\
\hline $\begin{array}{l}\text { Creatinine }(0.6- \\
1.1 \\
\mathrm{mg} / \mathrm{dL})\end{array}$ & 1.58 & 1 & 1.08 & 2.3 & 2 & 1.49 \\
\hline $\begin{array}{l}\operatorname{SGOT}(20-40 \\
\mathrm{IU} / \mathrm{L})\end{array}$ & 16.3 & 38.35 & 88 & 21.08 & 48.31 & 26.92 \\
\hline SGPT & 14.2 & 43.8 & 141 & 13.7 & 113 & 32.1 \\
\hline $\begin{array}{l}\text { Albumin } \\
(3.5-4.5 \mathrm{~g} / \mathrm{dL})\end{array}$ & 3.63 & 4.08 & 3.79 & 4.11 & 3.91 & 3.79 \\
\hline $\begin{array}{l}\text { Peripheral } \\
\text { blood film of } \\
\text { RBCs }\end{array}$ & $\begin{array}{l}\text { Microcytic } \\
\text { hypochromic, } \\
\text { anisocytosis }\end{array}$ & $\begin{array}{l}\text { Microcytic } \\
\text { hypo- } \\
\text { chromic }\end{array}$ & $\begin{array}{l}\text { Macro- } \\
\text { cyticnormo- } \\
\text { chromic }\end{array}$ & $\begin{array}{l}\text { Micro-cytic } \\
\text { Hypo-chromic, } \\
\text { Anispoikilo-cytosis }\end{array}$ & $\begin{array}{l}\text { Normo-cytic } \\
\text { Normo-chromic } \\
\text { Aniso-cytosis }\end{array}$ & $\begin{array}{l}\text { Aniso- } \\
\text { cytosis }\end{array}$ \\
\hline $\begin{array}{l}\text { Vit. B12 } \\
(\mathrm{pg} / \mathrm{mL})\end{array}$ & 83 & 100 & 640 & 146 & 191 & 148 \\
\hline $\begin{array}{l}\text { Folic acid } \\
(\mathrm{ng} / \mathrm{mL})\end{array}$ & 5.1 & 4 & 6.5 & 7.4 & 2.8 & 5.9 \\
\hline $\begin{array}{l}\text { S.Iron } \\
(\mathrm{mcg} / \mathrm{dL})\end{array}$ & 62 & & 69 & & 82 & 61 \\
\hline S.Ferritin $(\mathrm{ng} / \mathrm{mL})$ & 615.99 & & 456.1 & & 748 & 1745 \\
\hline $\begin{array}{l}\text { Pro } \\
\operatorname{BNP}(\mathrm{pg} / \mathrm{ml})\end{array}$ & 3108 & 565.9 & 1000 & 282.2 & 2877 & 684.2 \\
\hline $\mathrm{CRP}(\mathrm{mg} / \mathrm{L})$ & 9.55 & 78.4 & 2.7 & 2.32 & 12 & 1.82 \\
\hline $\begin{array}{l}\text { Cholesterol } \\
\text { (total) } \mathrm{mg} / \mathrm{dl}\end{array}$ & 238 & 284 & 215 & 230 & 181 & 176 \\
\hline TG $(\mathrm{mg} / \mathrm{dL})$ & 546 & 684 & 226 & 324 & 347 & 147 \\
\hline HDL (mg/dL) & 38.7 & 56.3 & 41 & 46.8 & 33.4 & 35.1 \\
\hline TSH (uIU/ml) & 1.03 & 0.22 & 1.22 & 0.67 & 2.67 & 2.22 \\
\hline Urine-R/M & $\begin{array}{l}10-12 \text { RBC } \\
\text { Prot+ }\end{array}$ & Normal & $\begin{array}{l}10-12 \text { RBC } \\
\text { Prot+ }\end{array}$ & Normal & $\begin{array}{l}\text { 10-12 RBC } \\
\text { Prot+ }\end{array}$ & $\begin{array}{l}\text { Nor- } \\
\text { mal }\end{array}$ \\
\hline
\end{tabular}

Hb- haemoglobin, TLC- Total leukocyte count, PLT- Platelets count, SGOT- Serum glutamate oxaloacetate transferase, SGPT- Serum glutamate pyruvate transferase, pro BNP- pro brain natriuretic peptide, CRP- C-reactive protein, TG- Triglyceride, HDL- High density lipoprotein, TSH- Thyroid stimulating hormone 